RESEARCH ARTICLE

\title{
A STUDY OF LIGHT INTENSITY AND FERTILIZER ON SOYBEAN IN ALBIZIA CHINENSIS AGROFORESTRY SYSTEM
}

\author{
Zulfikar Affandi ${ }^{1 *}$, Djoko Purnomo ${ }^{2}$, and Supriyono² \\ ${ }^{1}$ Master Program of Agronomy, Sebelas Maret University, Surakarta, Central Java 57126, Indonesia \\ ${ }^{2}$ Departement of Agrotechnology, Faculty of Agriculture, Sebelas Maret University \\ Submitted: 2018-12-05 Accepted: 2019-01-28
}

\begin{abstract}
One of the efforts to solve the decreasing of agriculture land area caused by land use change is through agroforestry system (AF), such as the cultivation among the Albizia chinensis trees. This research, along with the experiment, aims at studying the light characteristic of 1.5 years old Albizia $\mathrm{c}$ and the effect of fertilization on the growth of soybean and testing the soybean yield of Dega 1 varieties in agroforestry system based on Albizia c. Using the split-plot Randomized Block Design (RBD) as the experiment, the intensity of light was employed as the main plot whereas the fertilizer was used as the subplot in this study. There were four levels of light intensity: land with high light intensity (lands outside AF), rather high light intensity (radiation transmission fraction (RTF) among Albizia c 1425 ha $^{-1}$ density), medium-high light intensity (RTF among 2850 Albizia c density with pruned canopy), rather low light intensity (RTF among 2850 Albizia c density with unpruned canopy). As the subplot were some various fertilizers such as Albizia c litter, Albizia c litter + phosphorus (P) + potassium (K), and without any fertilization. Totally 12 treatments were obtained and each of those treatments was replicated three times, consequently consisting of 36 experiment units. The result of this research shows that Albizia c was exceedingly potential for the soybean cultivation with AF system. The passing light under the canopy (RTF) depended on the distance between each tree and could be improved by pruning the canopy. The increasing RTF increased vegetative and generative growth. The highest soybean production ( 3.3 tons ha ${ }^{-1}$ ) could be achieved in 2850 trees ha-1 density with pruned canopy (RTF: $49 \%$ equals to 28440 lux) compared with biomass production in open land ( 3.9 tons ha ${ }^{-1}$ ).
\end{abstract}

Keywords: Agroforestry, Albizia chinensis stand, Light intensity, Organic fertilizer, Soybean

How to Cite: Affandi, Z., Purnomo, D., and Supriyono. (2019). A Study of Light Intensity and Fertilizer on Soybean in Albizia Chinensis Agroforestry System. Sains Tanah Journal of Soil Science and Agroclimatology, 16(1): 46-56 (doi: 10.20961/stjssa.v16i1.25872)

Permalink/DOI: http://dx.doi.org/10.20961/stjssa.v16i1.25872

\section{INTRODUCTION}

In Indonesia, soybean (Glycine max L. Merr.) is a vegetable protein source and the main material for tempeh and tofu production (Kristanti et al. 2016) and soy sauce. The demand for soybean keeps increasing along

\footnotetext{
* Corresponding Author :

Email: zulfikar.affandi@yahoo.co.id
}

with the increasing number of population. Thus, the availability of domestic soybean is still a deficit. This deficit of quantity is predicted to keep going on 2019 up to be almost 2 tons, indicating that there are always imported soybeans every year (Riniarsi, 2015). The domestic soybean production is low as the farmers put more attention on rice and corn rather than on soybeans. Generally, Indonesian 
farmers plant soybeans at the end of the rainy season (following the rice and corn harvest), and soybeans have a short period of farming. Therefore, cropping management and soil cultivation are not quite optimum.

Agroforestry (AF) is a land cultivation system to settle any problem due to land-use change and food (Peng et al. 2009; Amin et al. 2016). An agroforestry system is developed to sustain an ecological balance; a mitigation for the negative impact because of the synergy between the forest stand and the agricultural land (Budiastuti \& Purnomo, 2012; Budiastuti, 2013; Dagar \& Tewari, 2017). In general, agroforestry comprises mixed garden, moor with trees, plantation, shrubland, house garden, community botanical garden with more variety of plants (Hadi et al. 2016). The agroforestry system as a combination of legumes (non-legume stand with legume plant, legume stand with a non-legume plant, and legume stand and plant) is known to be highly potential to produce organic products (pouring non-organic fertilizer or none of it). Albizia chinensis as a legume can maintain soil fertility through the fixation of atmospheric nitrogen (Mutua et al. 2014).

The light intensity becomes the main challenge in the agroforestry system, aside from water, and nutrients, because of the shade of tree canopy (Purnomo et al. 2013). The Radiation Transmission Fraction (RTF) ranged from 50 to $27 \%$ at a high light intensity (28500 and 15620 of 56920 lux) under the Albizia chinensis, Solomon variety. The tree's age was 1.5 years with the planting space of $(2.5 \times 3)$ meter $\left(1425\right.$ trees $\left.\mathrm{ha}^{-1}\right)$ and $(2 \times 1.5)$ meter ( 2850 trees ha $\left.{ }^{-1}\right)$. Canopy pruning can be done to increase the RTF. For instance, tree canopies with a density of 2850 trees in ha- ${ }^{-1} \mathrm{C}$ pruned $1 / 3$ lower from the canopy, RTF increased into $49 \%$ (from 15620 to 28440) (Affandi et al. 2018). Besides for light intensity increase purpose, the leftover leaves and branches of the canopy pruning are also serving as the potential green manure. Our preliminary study showed that Albizia chinensis stand with the population of 1425, 2850 trees $\mathrm{ha}^{-1}$, and pruned 2850 trees ha ${ }^{-1}$, provided the dry litter about $113.7,80.4$, and 62.4 tons ha ${ }^{-1}$ year ${ }^{-1}$ respectively (Affandi et al. 2018). Generally, soybeans are cultivated in the open land (light intensity 100\%); thus, there is a need to study about the effects of light intensity modification under Albizia chinensis trees and fertilizer on soybean in agroforestry.

\section{MATERIALS AND METHODS}

This research was conducted from November 2017 to February 2018 in Tasikmadu Village, which is geographically located on $7^{\circ} 34^{\prime} 19.2^{\prime \prime} \mathrm{S}$ and $110^{\circ} 55^{\prime} 65.2^{\prime \prime} \mathrm{E}$, with the elevation of $137 \mathrm{~m}$ above the sea level. The soil in the experiment area consisted of $0.25 \%$ of Nitrogen (medium), 7.15 ppm of Phosphorus (low), $0.28 \% \mathrm{me} \%$ of Potassium (low), and 5.88 of $\mathrm{C} / \mathrm{N}$ (low). The soil texture contained silt (49.10\%), clay (30.23\%) and sand (20.66\%), hence categorized as clay texture soil with low fertility (Affandi et al. 2018). The experiment was conducted in Albizia chinensis forest, with Solomon variety age 1.5 years with a population of 1425 and 2850 trees ha- ${ }^{-1}$ (planting spaces were $2.5 \times 3$ and $2 \times 1.5$, meter, respectively. A Dega- 1 soybean variety was used as the intercrop. The research used splitplot Randomized Block Design (RBD). The light intensity and fertilizer levels were the main plot and subplot, respectively. There were four levels of light intensity including high (lands outside Agroforestry), rather high (radiation RTF under 1425 Albizia chinensis ha $^{-1}$ ), medium (RTF under 2850 Albizia chinensis ha ${ }^{-1}$ with pruned canopy), and rather low (RTF under 2850 Albizia chinensis ha ${ }^{-1}$ with unpruned canopy). Moreover, the subplot consisted of three fertilizer types: Albizia chinensis litter, Albizia chinensis litter + phosphorus (P) + 
potassium (K), and without any fertilizer. Therefore, there were 12 treatment combinations with three replicates, hence 36 plots in total.

The land preparation was initiated by watering the land, then the parasite weeds were pruned, followed by raising the bed for plots of $(2 \times 1$ meters $)$ with space 30 centimeters. A Dega-1 soybean variety was planted using tugal (a kind of sharp wooden stick), 2 seeds per hole (the seed viability was 95.5\%). After 7 days, one of the growing soybeans were taken off so only one soybean remained in each hole. The treatment comprised replanting, watering in every afternoon (if there was no rain), weeding with a manual and rotating hoe, every week, spraying the pesticide once in three weeks. The organic fertilizer was made using the litter of Albizia chinensis leaves with the dosage of 2 tons $\mathrm{ha}^{-1}$ and the fertilization of SP36 and $\mathrm{KCl}$ with the dosage of 75-50 kgs ha-1. The fertilizer was applied when the soybean was 15 days old. The light transmission fraction from the Albizia chinensis canopy was measured by light meter Extech instruments positioned under the canopy and open land (out of AF) when the plant has reached the age of 45 days.

The observation of vegetative components consisted of Leaf Area Index (LAI), Specific Leaf Weight (SLW), Leaf-area ratio (LAR), and plant biomass. The generative components consisted of the number of seeds and its weight was measured. The data were then analyzed by SPSS Statistic 21.0 application, employing $F$ test with the level of 0.05 and 0.01 to find out the difference between treatments, followed by the Duncan Multiple Range Test (DMRT) if the $\mathrm{F}$ test was significantly different. A correlation and regression analysis were then performed to determine the relationship between variables.

Soil samples were collected at five points diagonally (4 points on the left and right edge, one point on the center). The soil chemical analyses including Nitrogen content (Kjeldahl method), P content (Olsen method), Ca (Ex method. NH4OAc $1 \mathrm{~N} \mathrm{pH} \mathrm{7.00),} \mathrm{organic} \mathrm{matter}$ (Walkey \& Black), $\mathrm{pH}$ (using $\mathrm{pH}$ meter cup electrode), and the physic characteristic analyses were conducted at Soil Chemistry and Soil Physic Laboratory, Faculty of Agriculture, Sebelas Maret University. The analyses of leaf $\mathrm{N}$ and chlorophyll content were measured by spectrophotometer UV Mini-1240. The growth analyses through the measurements of leaf area and plant biomass were performed at 15 , 30 , and 45 days after planting, respectively.

\section{RESULTS}

The initial soil characteristics containing medium Nitrogen and low of Phosphorus, Potassium also $\mathrm{C} / \mathrm{N}$ ratio, hence low soil fertility. This condition was possibly due to the fact that Albizia chinensis tended to be over early to give a kind of contribution for the land fertility (a biogeochemical cycle is yet under homeostasis). Furthermore, there was still an open space between trees, which then caused the rain to drop on the ground and resulted in erosion. Infiltrated and percolated water led the soil nutrient to be absorbed by the weeds or leaching (Affandi et al. 2018).

\section{Vegetative and photosynthesis components}

A leaf has a major role in plant growth since it is the photosynthesis organ, in which significantly determined by the leaf area and thickness. During the vegetative grew at the maximum level ( 45 days after planting), the soybeans' leaf area index (LAI) under different light intensity were differed due to different RTF, but not significantly different due to fertilization. The LAI of soybean under the high intensity of light was 1.42, meanwhile, those under the canopy with RTF of 50, 49 and $27 \%$ (28500, 15620, 28440 Lux) were 1.22, 1.67, and 0.97, respectively (Table 2 ). The light 
interceptions in RTF of $100,50,49$, and $27 \%$ were $74.17,61.19,69.19,69.12$ and $67.47 \%$, respectively.

Table 1 also shows the fertilization was not significantly affected the leaf thickness (defined in Specific Leaf Weight /SLW), while the light intensity significantly affected the SLW (Table 2). The SLW was bigger under the trees with RTF of 100 and $49 \%\left(0.004 \mathrm{~g} \mathrm{~cm}^{-2}\right)$ compared to those under RTF of 50 and $27 \%$ $\left(0.003 \mathrm{~g} \mathrm{~cm}^{-2}\right)$. The correlation of LAI and SLW (Table 3 ), tested by correlation test, showed that correlation coefficient ( $r$ value) was 0.4 (middle-low correlation).

The Albizia chinensis litter and PK fertilization did not significantly affect the Leaf Area Ratio (LAR). In the meantime, the LAR under RTF of 100 of $49 \%$ was 145.13 and
$147.42 \mathrm{~cm}^{2} \mathrm{~g}^{-1}$, respectively, and significantly to those under RTF of 50 and $27 \%$ (212.20 and $208.41 \mathrm{~b} \mathrm{~cm} \mathrm{~cm}^{-1}$, respectively) (Table 2). The correlation (Table 3 ) of Biomass and LAR was 0.45 (positive), the analysis of regression of light and biomass correlation supported that statement (Figure 1). Figure 1 shows when it was 15 and 30 days after planting, the RTF effects on the biomass tended to be low, indicated by $R^{2} 0.0007$ and 0.37 , respectively. However, when it was 45 days old, the increased light intensity on the biomass was relatively strong $\left(R^{2}=0.61\right)$ (Figure 1$)$. Plant biomass, which is not significantly different at all levels at all fertilization dosages (Table 1), proved that soil nutrients in the location were sufficiently available.

Table 1. The effect of fertilizer on soybean vegetative growth at 45 days after planting

\begin{tabular}{lcccc}
\hline \multicolumn{1}{c}{ Parameter } & P1 & P2 & P3 & Sig. \\
\hline Biomass $(\mathrm{g})$ & 3.92 & 3.49 & 3.34 & $\mathrm{~ns}$ \\
LAl & 1.14 & 1.13 & 1.16 & $\mathrm{~ns}$ \\
LSW $\left(\mathrm{g} \mathrm{cm}^{-2}\right)$ & 0.003 & 0.003 & 0.003 & $\mathrm{~ns}$ \\
LAR $\left(\mathrm{cm}^{-2} \mathrm{~g}^{-1}\right)$ & 157.70 & 169.47 & 207.70 & $\mathrm{~ns}$ \\
N Leaf $(\%)$ & 1.75 & 1.79 & 1.83 & $\mathrm{~ns}$ \\
\hline
\end{tabular}

Note: P1: the fertilization of Albizia chinensis litter 2 tons ha ${ }^{-1} ; \mathrm{P} 2:$ Albizia chinensis litter phosphorus $(\mathrm{P})+$ potassium (K) (SP36 and Kcl with dosage of 75 and $50 \mathrm{kgs} \mathrm{ha}^{-1}$ ); P3: no fertilizer; ns: not significant; $\alpha=5 \%$; LAR $=$ Leaf Area Ratio

Table 2. The effects of light intensity on soybean vegetative growth at 45 days after planting

\begin{tabular}{lccccc}
\hline \multirow{2}{*}{ Parameter } & \multicolumn{5}{c}{ RTF (\%) } \\
\cline { 2 - 6 } & $\mathbf{2 7}$ & $\mathbf{4 9}$ & $\mathbf{5 0}$ & $\mathbf{1 0 0}$ & Sig. \\
\hline Biomass (g) & $3.05 \mathrm{a}$ & $3.95 \mathrm{~b}$ & $2.43 \mathrm{a}$ & $4.89 \mathrm{c}$ & $\mathrm{s}$ \\
LAI & $0.96 \mathrm{a}$ & $1.16 \mathrm{a}$ & $1.02 \mathrm{a}$ & $1.42 \mathrm{~b}$ & $\mathrm{~s}$ \\
LSW $\left(\mathrm{g} \mathrm{cm}^{-2}\right)$ & $0.003 \mathrm{~b}$ & $0.004 \mathrm{~b}$ & $0.003 \mathrm{a}$ & $0.004 \mathrm{c}$ & $\mathrm{s}$ \\
LAR $\left(\mathrm{cm}^{-2} \mathrm{~g}^{-1}\right)$ & $208.42 \mathrm{~b}$ & $147.42 \mathrm{a}$ & $212.20 \mathrm{~b}$ & $145.13 \mathrm{a}$ & $\mathrm{s}$ \\
$\mathrm{N}$ Leaf $(\%)$ & $2.01 \mathrm{c}$ & $1.77 \mathrm{~b}$ & $1.75 \mathrm{~b}$ & $1.63 \mathrm{a}$ & $\mathrm{s}$ \\
\hline
\end{tabular}

Note: s: significantly different at $\alpha=5 \%$; means followed with the same letter in the same row are not significantly different; $L A R=$ Leaf Area Ratio 
Table 3. Pearson's correlation matrix between parameters

\begin{tabular}{lrrrrrrrrr}
\hline \multicolumn{1}{c}{ Parameter } & RTF & Biomass & \multicolumn{1}{c}{ LAI } & SLW & LAR & Chlorophyll & N Leaf & Pod & Seed \\
\hline RTF & - & & & & & & & & \\
\hline Biomass & 0.79 & & & & & & & \\
Sig. & 0.001 & - & & & & & & & \\
\hline LAl & 0.96 & 0.93 & & & & & & & \\
Sig. & 0.000 & 0.000 & - & & & & & & \\
\hline SLW & 0.68 & 0.90 & -0.40 & & & & & & \\
Sig. & 0.000 & 0.00 & 0.015 & - & & & & & \\
\hline LAR & -0.69 & 0.45 & -0.86 & -0.99 & & & & \\
Sig. & 0.074 & 0.000 & 0.503 & 0.15 & - & & & \\
\hline Chorophyll & 0.45 & -0.14 & 0.18 & -0.33 & 0.34 & & & \\
Sig. & 0.536 & 0.860 & 0.825 & 0.665 & 0.664 & & - & & \\
\hline N Leaf & & & & & & & & & \\
Contain & -0.64 & -0.09 & -0.45 & -0.20 & 0.17 & -0.67 & & \\
Sig. & 0.000 & 0.020 & 0.000 & 0.426 & 0.331 & 0.327 & - & \\
\hline Pod & 0.63 & 0.98 & 0.83 & 0.90 & 0.98 & -0.34 & 0.10 & \\
Sig. & 0.009 & 0.000 & 0.003 & 0.000 & 0.017 & 0.664 & 0.327 & - \\
\hline Seed & 0.68 & 0.99 & 0.85 & 0.87 & -0.89 & -0.25 & 0.08 & 0.99 \\
Sig. & 0.004 & 0.000 & 0.004 & 0.000 & 0.11 & 0.749 & 0.336 & 0.000 \\
\hline & & & & & & & & \\
\hline
\end{tabular}
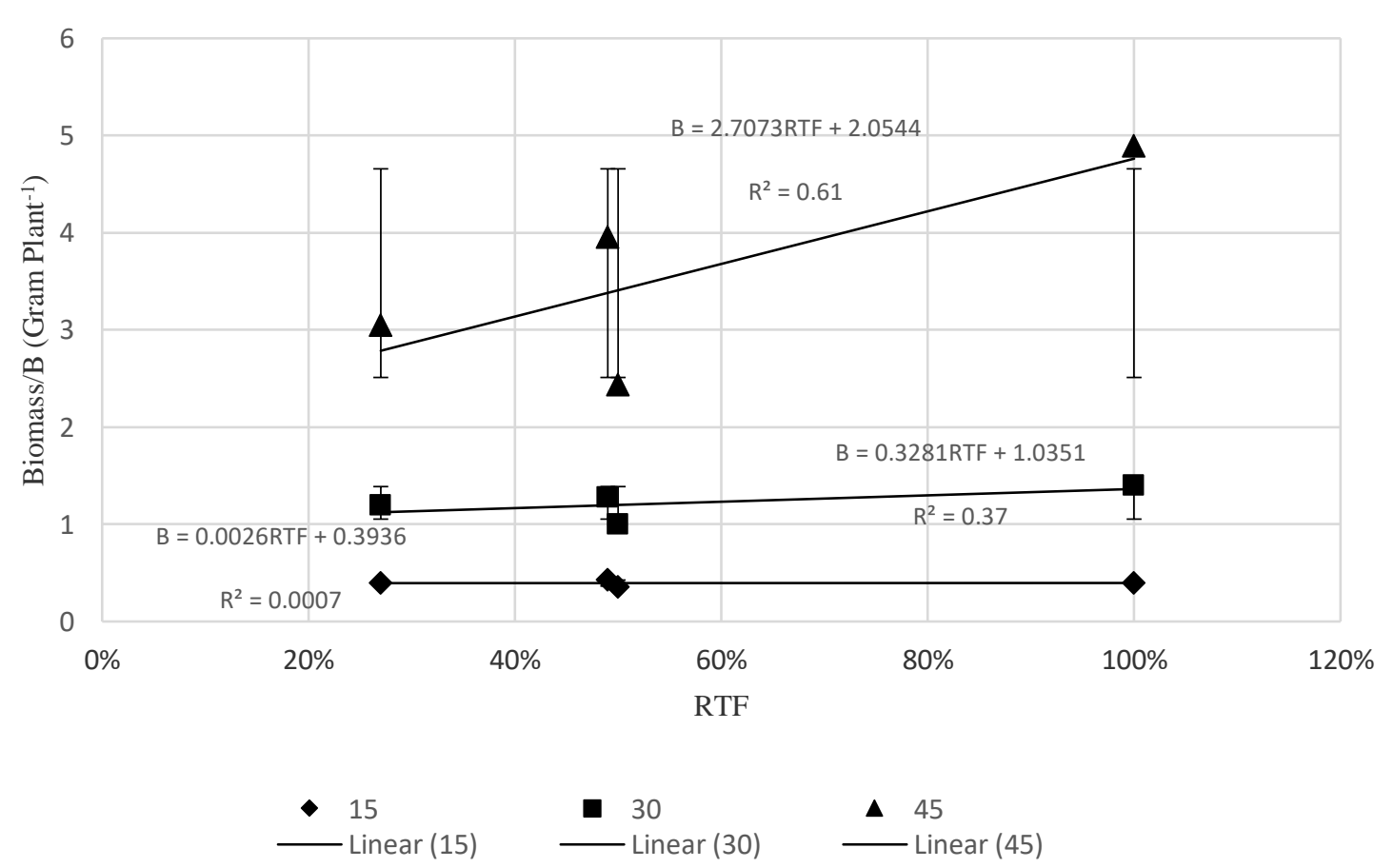

Figure 1. The effect of increasing light intensity (RTF) on biomass. Note: 15, 30 and 45 are soybean's Day After Plant (DAP). 


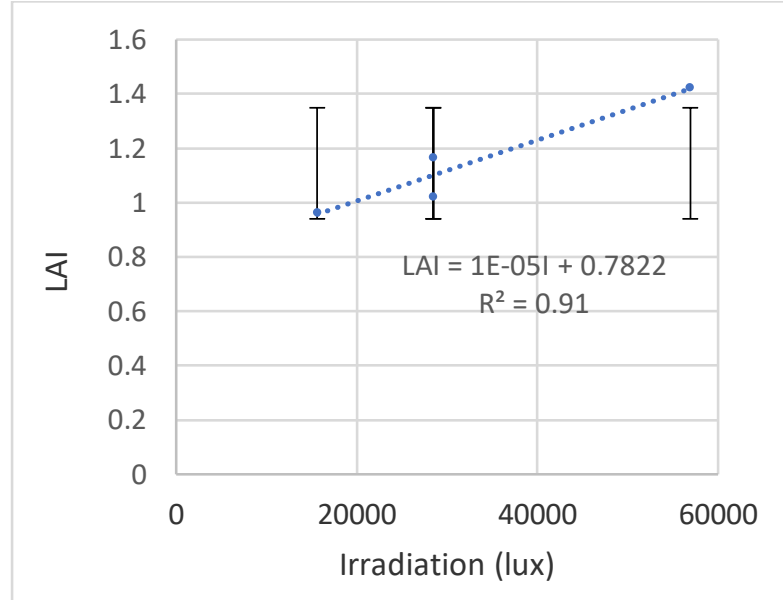

(a)

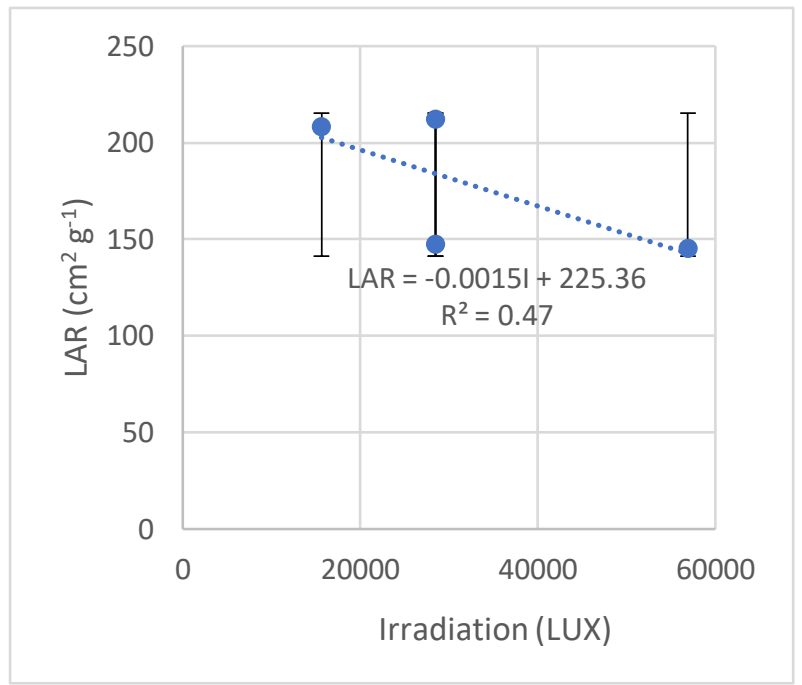

(c)

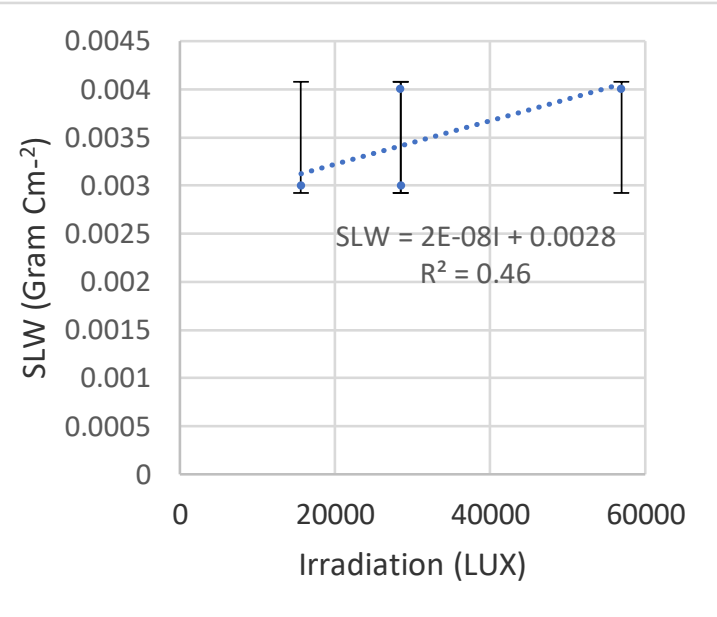

(b)

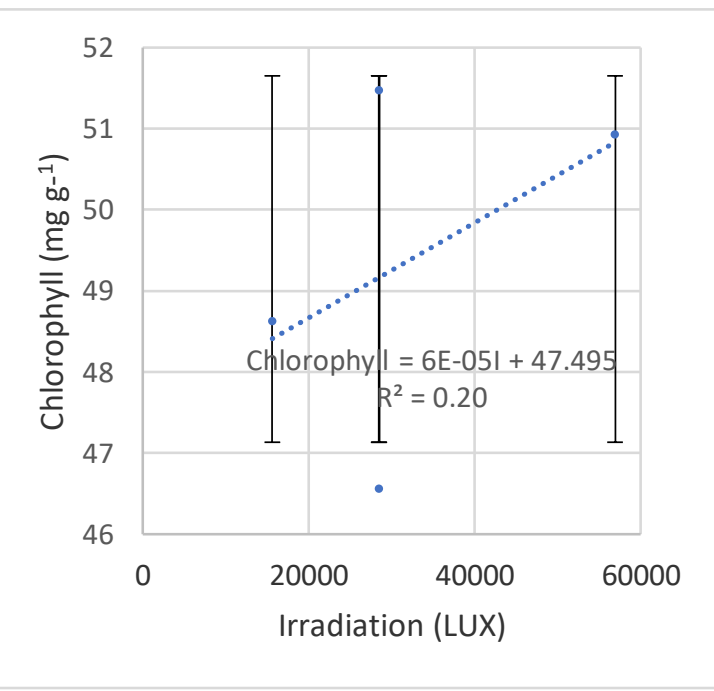

(d)

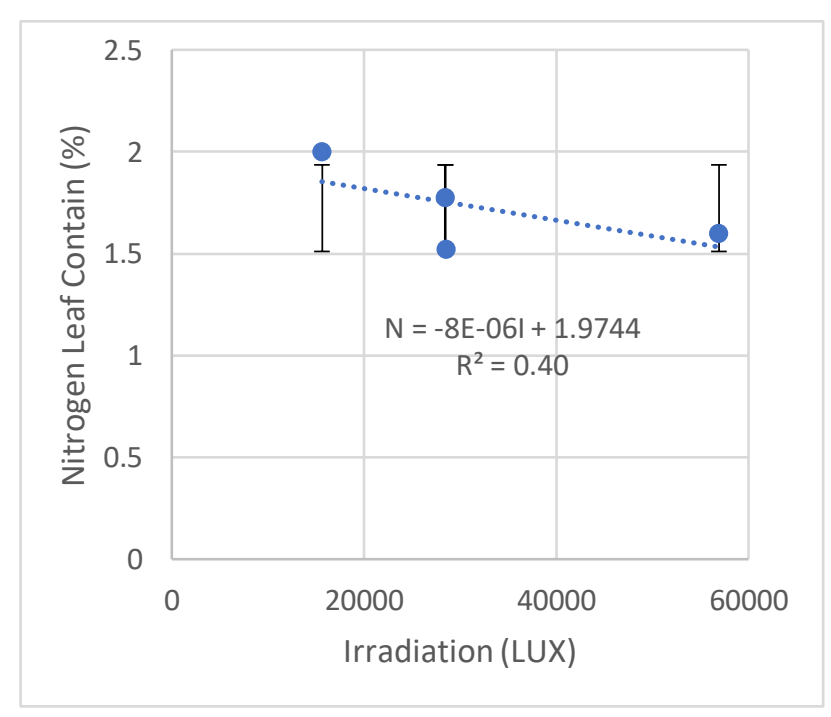

(e)

Figure 2. The effects of irradiation in LAI (a), SLW (b), LAR (c), Chlorophyll total (d) and leaf nitrogen content $(\mathrm{N})$ 


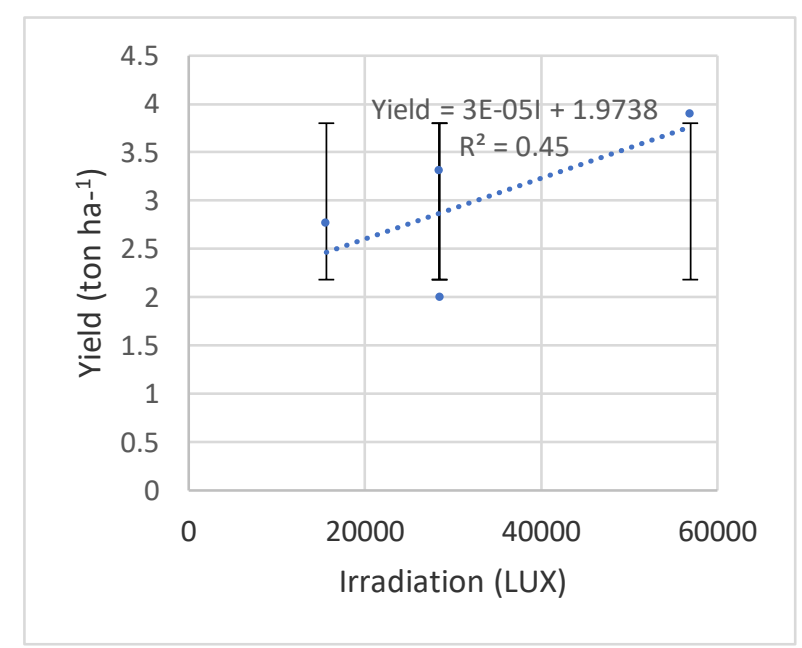

(a)

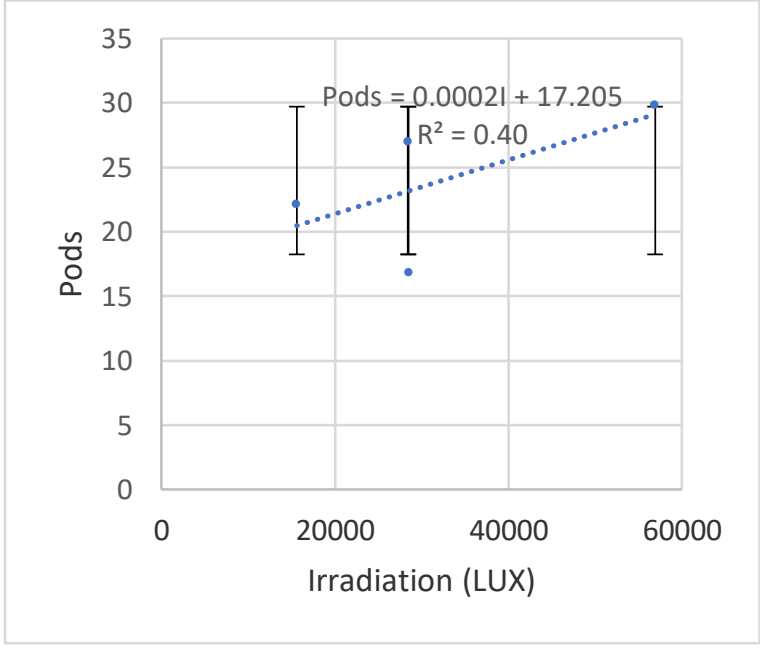

(b)

Figure 3. The effects of light intensity on the yield (a) and number of pods (b)

When the vegetative growth was maximum, the light determined the LAI, SLW, leaf nitrogen content $(\mathrm{N})$ and Chlorophyll (Figure 2). The higher the RTF, the higher the LAl as well (Figure 2a), it means that the leaf area became wider hence the leaf will be thinner (reflected as SLW). However, in this case, the increase in RTF generated increase SLW $\left(R^{2}=0.45\right)$. The correlation between chlorophyll and SLW was negative and weak ( $r$ $=-0.33$ ) (Table 3), which indicates that the mesophyll cells were not increased although the leaf became thicker.

\section{Generative components}

The soybean pods number outside AF (high intensity of light, 56920 lux) and in Agroforestry system with unpruned Albizia chinensis (2850 tree ha-1 28440 lux), were 30 and 27 (not significant), respectively (Table 5), while it was 22 under the RTF of $27 \%$ (15620 lux) (Table 5). There is a positive correlation between RTF and the number of pods ( $r$ : 0.63) (Table 3).

The weight of soybean under RTF of 56920, 28500, and 15620 lux were 15.60, 7.98, 13.22 and $11.05 \mathrm{~g}$ plant $^{-1}$ (Table 5), respectively, with the yield $1.9,3.3$, and 2.7 tons $\mathrm{ha}^{-1}$, respectively. When the intensity of light decreased to $50 \%$, the pods formation, and seed-filling was not disrupted, shown in Table 5 whereas the light intensity declined $50 \%$ but the yield was high ( 33 tons ha ${ }^{-1}$ ). It is strengthened by the fact that the weight of 100 seeds was $26.20 \mathrm{~g}$, which means that it was almost the same as the variety description $(22.98 \mathrm{~g})$. RTF and pods had a positive correlation ( $r=0.63$ ) (Table 3 ) and regression test shows that the light affected the soybean production $\left(R^{2}=0.45\right)$ (Figure $\left.3 a\right)$.

Table 4. The effects of fertilizers on pods number and seed yield

\begin{tabular}{ccccc}
\hline Parameter & P1 & P2 & P3 & Sig. \\
\hline Pods & 22.85 & 24.54 & 24.68 & ns \\
Seeds plant $^{-1}$ & 11.55 & 12.60 & 11.74 & ns \\
\hline
\end{tabular}

Note: P1: the fertilization of Albizia chinensis litter 2 tons ha ${ }^{-1} ; \mathrm{P} 2$ : Albizia chinensis litter phosphorus (P) + potassium (K) (SP36 and Kcl with dosage of 75 and $50 \mathrm{kgs} \mathrm{ha}^{-1}$ ); P3: no fertilizer; ns: not significant; $\alpha=5 \%$. 
Table 5. The effects of light intensity on pods number and seed yield

\begin{tabular}{|c|c|c|c|c|c|}
\hline RTF & 15620 & 28440 & 28500 & 56920 & Sig. \\
\hline Pods & $22.16 \mathrm{~b}$ & $27.02 c$ & $16.91 a$ & $30.00 c$ & $\mathrm{~s}$ \\
\hline Seed Plant ${ }^{-1}$ & $11.05 b$ & $13.22 \mathrm{c}$ & $7.98 a$ & $15.60 d$ & $\mathrm{~s}$ \\
\hline
\end{tabular}

Note: s: significantly different; means followed with the same letter in the same row are not significantly different at $\alpha=5 \%$

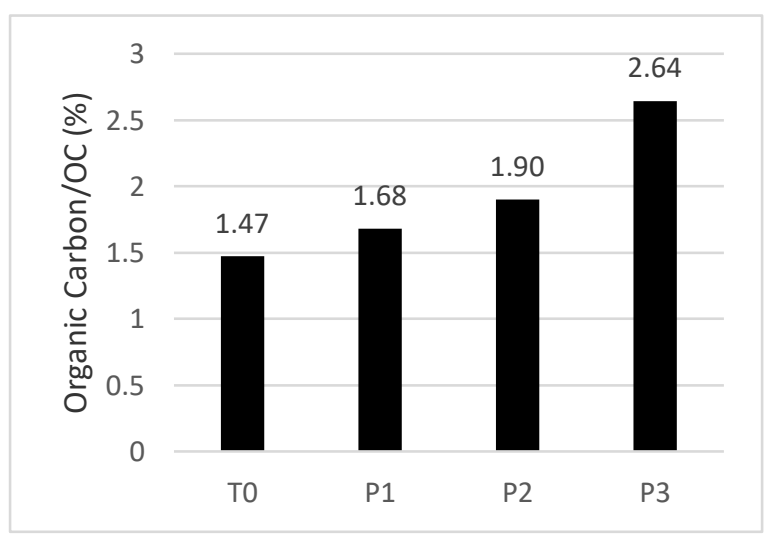

(a)

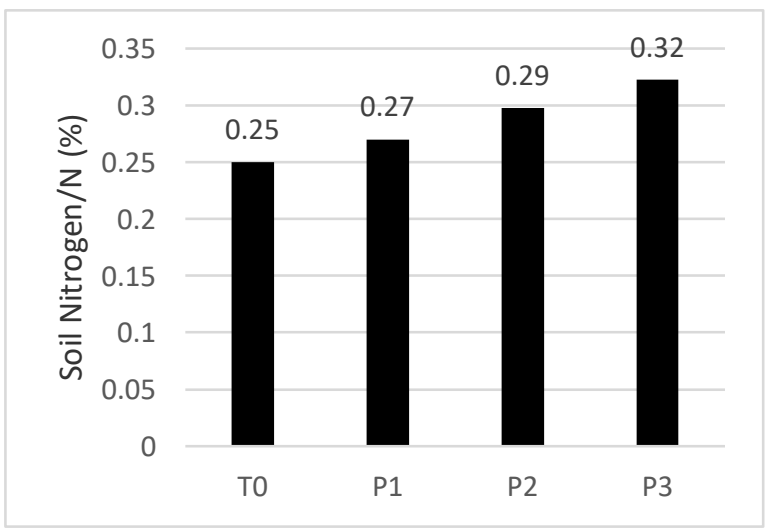

(c)

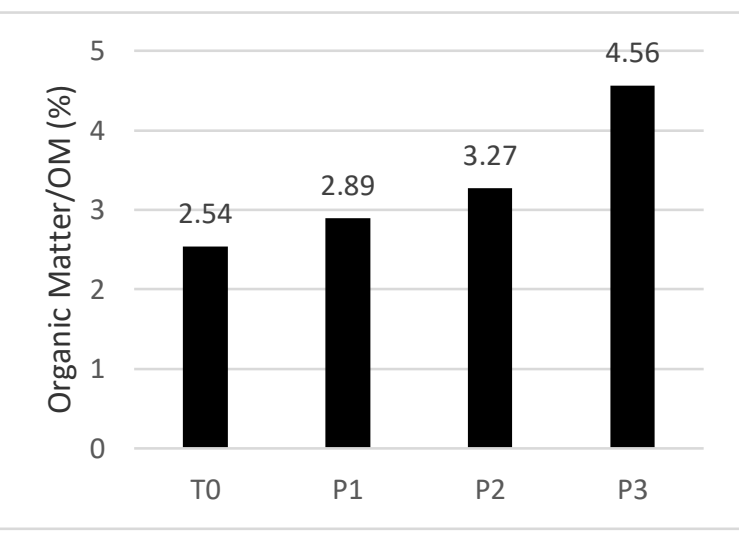

(b)

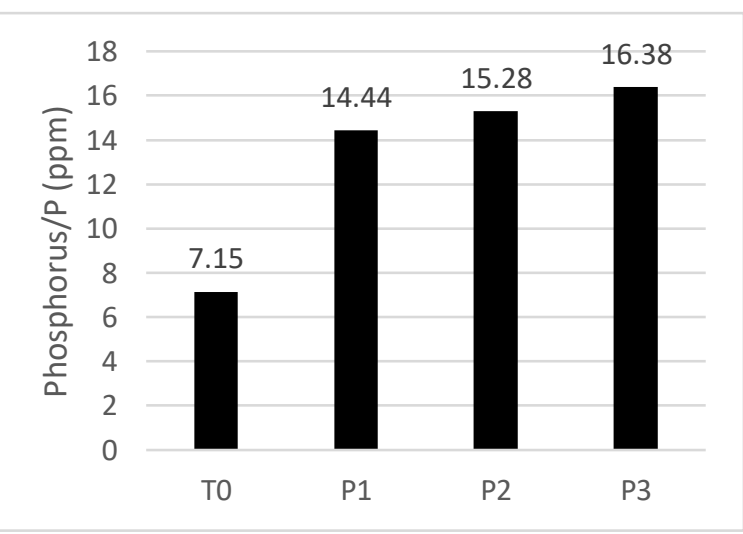

(d)

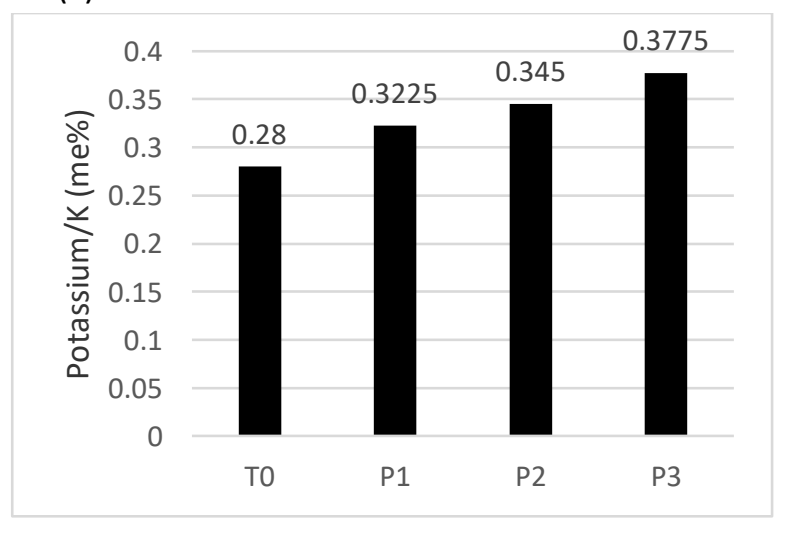

(e)

Figure 4. The initial and final soil analysis of organic carbon content (a), organic matter (b), P available (c), $\mathrm{N}$ total (d), and exchanged $\mathrm{K}$ (e). Note: T0: The initial soil analysis; P1: the fertilization of Albizia chinensis litter 2 tons ha ${ }^{-1}$; P2: Albizia chinensis litter phosphorus (P) + potassium (K) (SP36 and Kcl with the dosage of 75 and $\left.50 \mathrm{kgs} \mathrm{ha}^{-1}\right)$; P3: no fertilizer 


\section{RESEARCH ARTICLE}

Figure 4 shows soil organic carbon, organic matter, $\mathrm{P}$ available, $\mathrm{N}$ total, and exchanged $\mathrm{K}$ were higher under fertilization with Albizia chinensis litter 2 tons ha ${ }^{-1}$, Albizia chinensis littered phosphorus $(\mathrm{P})+$ potassium (K) (SP36 and $\mathrm{KCl}$ with the dosage of 75 and 50 $\mathrm{kgs} \mathrm{ha}^{-1}$ ) than initial characteristics. The final analysis found the soil without fertilizer shows that organic carbon content (2.64\%), OM (4.56\%), P (16.38 ppm), N total (0.32\%), and exchanged $\mathrm{K}(0.38 \mathrm{me} \%)$ were higher than the fertilized soil (ranged 1.68-1.90\%, 2.89-3.27\%, $14.44-15.28 \mathrm{ppm}, \quad 0.27-0.29 \%$ and $0.32-$ $0.34 \mathrm{me} \%$, respectively) (Figure 4).

\section{DISCUSSION}

Nitrogen and $\mathrm{pH}$ content of the research site was low (Affandi et al. 2018), hence less nutrient for the plants if soil $\mathrm{pH}$ extremely acidic (Sudomo \& Handayani, 2013). The small content of nutrient and organic matter in acidic soil caused $\mathrm{Al}, \mathrm{Fe}, \mathrm{Ca}$, and $\mathrm{Mg}$ dissolved in soil particles, causing the ion P contained in the soil was bound by Al and Fe oxidation (Kusumastuti, 2014). The slow organic matter decomposition was detected through $\mathrm{C} / \mathrm{N}$ (Sudomo \& Handayani, 2013). Based on Affandi et al. (2018), the $\mathrm{C} / \mathrm{N}$ under Albizia chinensis was low (5.88), indicating the available organic matter was simply decomposed.

The LAI was categorized as low because ideally, the LAl of the plants at the open field is 5 (Sitompul, 2016). The LAI was low due to low light intensity (Table 2). Bilman (2001) states that LAI under light interception 50, 90, and $95 \%$ was $\leq 1, \leq 3$, and $\leq 4$, respectively. Furthermore, the relationships between LAI and SLW is middle-low (Table 3), indicating a bigger leaf area leads to thinner leaf. Setiawan \& Sukamto (2016) states that light transmission through the leaf depended on the thickness of the leaf, which is defined as a Specific Leaf Area (SLA).
The Leaf-area ratio (LAR) is the capability of leaf per unit to produce biomass. Biomass had a positive correlation with LAR means biomass came from leaf photosynthates. The increase LAR followed by the increased biomass indicating the photosynthates effectivity. The determinant component of plants growth was the efficiency of light intensity concerning light interception and biomass production (Pembengo et al. 2012). Budiastuti \& Purnomo (2012) states that solar radiation, leaf orientation and position, the environment, and the types of plants control the photosynthesis process.

Leaf thickness should be linear with mesophyll because the chlorophyll content is higher in the thick leaf (Megia et al., 2015; Prakoso et al. 2018), but the correlation between chlorophyll and SLW was negative (Table 3). Furthermore, chlorophyll and $\mathrm{N}$ content negatively correlated, while normally it is positive (Fritschi \& Ray, 2007). The RTF determined the chlorophyll formation process (Taiz et al. 2015), but since it was not supported by $\mathrm{N}$, the increased RTF causing photosynthesis decrease (represented by SLW) with $\mathrm{R}^{2}=0.4$ (Figure 2). It explains that there was assimilation remobilization of the vegetative part to the seed ( $r$ of $N$ vs. chlorophyll $=-0.67$ ).

The effects of fertilizer on the vegetative growth were not significant (Table 1), which also occurred at the generative growth (Table 4), due to assimilation remobilization. During the vegetative growth, the light determined the formation of seed-filling and pods (Figure 3 ), whereas $50 \%$ lower of light intensity did not disrupt pods formation. The higher the RTF, the more soybean pods formed hence the light intensity affects the number of pods (Figure 3 ). This pod formation later is followed by seedfilling reflected by the weight of seed produced. (Wahyu et al. 2010) reported 50\% of shade intensity decreased the number of pods 
per bunch and the production of seeds per hectare.

The soil nutrient content after treatments was greater than the initial (Figure 4), that is because the land cultivating during preparation increased aeration and drainage, consequently increased the OM from parasite weeds decomposition (McCauley et al. 2017; Liu et al. 2006). A study (Ziblim et al. 2012) reported the soil under Albizia chinensis stand contained higher nitrogen, organic carbon and phosphorus. It is distinct that fertilization promoting faster decomposition process (especially inorganic fertilizer). Therefore, the soil nutrients would be absorbed by the plant, evaporated, or leached rapidly. That is why soybean culture did not need fertilizer because fertilization did not give any effect on the yield.

\section{CONCLUSION}

The albizia chinensis canopy of 1.5 years old with different spacing resulted in different light intensity ranged from 15,620 to 28,500 lux. In this regard, fertilization has no effects on the generative and vegetative growth of soybean. The soybean yield ranged 1.9 - 3.3 tons ha-1.

\section{REFERENCES}

Affandi, Z., Purnomo, D., \& Supriyono (2018). Potensi Sengon dalam Sistem Agroforestri Berdasar Karakteristik Pohon Bagi Ketersediaan Cahaya dan Nutrisi, Prosiding Seminar Nasional Dalam Rangka Dies Natalis UNS Ke 42, 2(1), 3441.

Amin, M., Rachman, I., and Ramlan, S. (2016). Jenis Agroforestri dan Orientasi Pemanfaatan Lahan di Desa Simoro Kecamatan Gumbasa Kabupaten Sigi. Warta Rimba, 4(1), 97-104.

Bilman, W. S. (2001). Analisis Pertumbuhan Tanaman Jagung Manis (Zea mays saccharata), Pergeseran Komposisi Gulma pada beberapa Jarak Tanam. Jurnal IImu-IImu Pertanian, 3(1), 25-30.
Budiastuti, S. \& Purnomo, D. (2012). Agroforestri: Bentuk Pengelolaan Lahan Berwawasan Lingkungan. Surakarta: UNS Press.

Budiastuti, S. (2013). Sistem Agroforestri Sebagai Alternatif Hadapi Pergeseran Musim Guna Pencapaian Keamanan Pangan. Jurnal Ekosains, 5(1), 1-5.

Dagar, J. C., \& Tewari, V. P. (2017). Evolution of Agroforestry as a Modern Science. In Agroforestry (pp. 13-90). Singapore: Springer Nature Pte Ltd.

Fritschi F, \& Ray, J. D. (2007). Soybean Leaf Nitrogen, Chlorophyll Content, and Chlorophyll a/b Ratio. Photosynthetica, 45(1), 92-98.

Hadi, E. E. W., Widyastuti, S. M., \& Wahyuono, S. (2016). Keanekaragaman dan Pemanfaatan Tumbuhan Bawah Pada Sistem Agroforestri di Perbukitan Menoreh, Kabupaten Kulon Progo. Jurnal Manusia Dan Lingkungan, 23(2), 206-215.

Ziblim, I. A., Tom-dery, D., \& Kwadwo, K. A. (2012). Assessment of soil quality improvement under Teak and Albizia. Journal of Soil Science and Environmental Management, 3(4), 91-96. 10.5897/JSSEM11.151

Kristanti, N. E., Guritno, A. D., \& Supartono, W. (2016). Analysis of Supply Chain Management Soybean (Glycine max L . Merr) Based on Quality and Structure Logistics Cost. ICOA Conference Proceedings Vol. 3, pp. 125-128. Dubai, UAE: KnowledgE Publishing.

Kusumastuti, A. (2014). Dinamika P Tersedia, $\mathrm{pH}$, C-Organik dan Serapan P Nilam (Pogostemon cablin Benth.) pada Berbagai Aras Bahan Organik dan Fosfat di Ultisols. Jurnal Penelitian Pertanian Terapan, 14(3), 145-151.

Liu, X., Herbert, S. J., Hashemi, A. M., Zhang, X., \& Ding, G. (2006). Effects of Agricultural Management on Soil Organic Matter and Carbon Transformation - a Review. Plant Soil Environ, 12, 531-543.

Megia, R., Ratnasari, \& Hadisunarso. (2015). Karakteristik Morfologi dan Anatomi, serta Kandungan Klorofil Lima Kultivar Tanaman Penyerap Polusi Udara Sansevieria trifasciata. Jurnal Sumberdaya Hayati, 1(2), 34-40. 
Mutua, J., Muriuki, J., Gachie, P., Bourne, M., \& Capis, J. (2014). Conservation Agriculture With Trees: Principles and Practice $A$ simplified guide for Extension Staff and Farmers. Nairobi, Kenya: World Agroforestry Centre, (ICRAF).

Pembengo, W., Handoko, \& Suwarto. (2012). Efisiensi Penggunaan Cahaya Matahari oleh Tebu pada Berbagai Tingkat Pemupukan Nitrogen dan Fosfor. Journal Agronomi Indonesia , 40(3), 211-217.

Peng, X., Zhang, Y., Cai, J., Jiang, Z., \& Zhang, S. (2009). Photosynthesis, Growth, and Yield of Soybean and Maize in a Tree-based Agroforestry Intercropping System on the Loess Plateau. Agroforestry System, 76(3), 569-577. 10.1007/s10457-0099227-9

Prakoso, I.D, Indradewa, D., \& Sulistyaningsih, E. (2018). Pengaruh Dosis Urea terhadap Pertumbuhan dan Hasil Kedelai (Glycine max L. Merr.) Kultivar Anjasmoro. Vegetalika, 7(3), 16-29.

Purnomo, D., Sitompul S. M., \& Budiastuti, S. Mth. (2013). Solar Radiation in Agroforestry System. Journal of Agricultural Science and Technology, 3(8), 351-356.

Riniarsi, D. T. (2015). Outlook: Komoditas Pertanian Tanaman Pangan Kedelai. Jakarta, Indonesia: Pusat Data dan Sistem Informasi Pertanian Kementerian Pertanian.
McCauley, A., Jones, C., \& Olson-rutz, K. (2017). Soil pH and Organic Matter. Nutrient Management Module no. 8 (pp 1-16). Montana, USA: Montana State University. Sitompul, S. M. (2016). Analisis Pertumbuhan Tanaman. Malang: UB Press.

Sudomo, A., \& Handayani, W. (2013). Karakteristik Tanah Pada Empat Jenis Tegakan Penyusun Agroforestry Berbasis Kapulaga (Amomum compactum Soland ex Maton). Jurnal Penelitian Agroforestry, 1(1), 1-11. 10.1117/12.907083

Setiawan \& Sukamto. (2016). Karakter Morfologis dan Fisiologis Tanaman Nilam di Bawah Naungan dan Tanpa Naungan. Buletin Penelitian Tanaman Rempah dan Obat, 27(2), 137-146.

Taiz, L., Zeiger, E., Moller, I.M., \& Murphy, A. (2015). Plant Physiology and Development 6th ed. Massachusetts, USA: Sinauer Associates Inc. Pub.

Wahyu, G., Susanto, A., \& Sundari, T. (2010). Pengujian 15 Genotipe Kedelai pada Kondisi Intensitas Cahaya $50 \%$ dan Penilaian Karakter Tanaman Berdasarkan Fenotipnya. Jurnal Biologi Indonesia, 6(3), 459-471. 